\title{
A Silurian oncocerid with preserved colour pattern and muscle scars (Nautiloidea)
}

\author{
ŠTĚPÁN MANDA \& VOJTĚCH TUREK
}

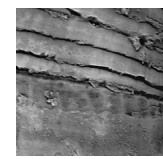

\begin{abstract}
A new genus Euryrizocerina (Nautiloidea, Oncocerida, Oonoceratidae) from the late Silurian strata of Bohemia (Prague Basin) is established. Two species are included within the genus: the type species E. normata (Barrande, 1877) and E. pulchra sp. nov. The genus is striking for two features - the preservation of shell colouration and muscle attachment scars in the type species. These features are reliable for taxonomic and palaeoecological analysis of nautiloids, but due to their only occasional preservation in fossils, the evolutionary trends of these characters remain poorly understood. The colour pattern of Euryrizocerina consists of irregular pulsed transverse bands that clearly differ from the colour patterns known in other oncocerids where rather regular wave-like or zig-zag bands have been observed. It is questionable whether the new type of colouration represents a taxonomic or morphotypic feature, as Euryrizocerina is the first oncocerid to be recognised with a highly curved shell that retains colouration. Oncocerids exhibit multiple paired muscle scars and there is uncertainty whether these represent an original metamery, inherited from a cephalopod ancestor, or a derived feature. Euryrizocerina possesses four pairs of retractor muscle scars, but its ancestor "Oonoceras" fraternum and allied forms, possess multiple pairs of muscle scars around the base of the body-chamber, as do the majority of oncocerids. A similar reduction in the number of muscle scar pairs has been documented in Devonian rutoceratoids. The high evolutionary plasticity of muscle attachments patterns, as indicated by these examples, suggests that the muscle complex and its attachment to the shell was under adaptive control and is more likely to reflect the form of the shell and the mode of life of the organism. It seems likely that shell colouration and the pattern of attachment of the retractor muscles have a much more complex evolutionary history (including several convergences) than was previously supposed. • Key words: Nautiloidea, Oncocerida, colour pattern, muscle scars, Silurian, Prague Basin, new taxa.
\end{abstract}

MANDA, S. \& TUREK, V. 2009. A Silurian oncocerid with preserved colour pattern and muscle scars (Nautiloidea). Bulletin of Geosciences 84(4), 755-766 (7 figures). Czech Geological Survey, Prague. ISSN 1214-1119. Manuscript received October 30, 2009; accepted in revised form December 22, 2009; published online December 30, 2009; issued December 31, 2009.

Štěpán Manda, Czech Geological Survey, P.O.B. 85, Praha 011, 118 21, Czech Republic; stepan.manda@geology.cz• Vojtěch Turek, National Museum, Department of Palaeontology, Václavské náměstí 68, 11579 Praha 1, Czech Republic; vojtech.turek@nm.cz

The shell in nautiloids serves a hydrostatic, hydrodynamic and protective function. Final shell form reflects evolutionary interplay between both these functions. Disparity of shell form in nautiloids is striking and almost all geometrically possible forms evolved at some time during the Palaeozoic. The first classifications of cephalopods in the $19^{\text {th, }}$ and in particular during the early $20^{\text {th }}$ century, used morphotype as the main diagnostic feature. Hyatt (1883, 1994, 1900) and later Flower \& Kummel (1950) adopted new systematic approaches emphasising the importance of the morphology of the siphonal tube. Subsequent studies of muscle scars (e.g., Mutvei 1964, Evans 2005, Kröger \& Mutvei 2005), embryonic development (e.g., Manda 2008), and shell colouration (e.g., Kobluk \& Mapes 1989, Turek 2009) provided important additional data with significant implications in relation to the taxonomy and palaeo- ecology of nautiloids. Some of this data is not yet fully incorporated into concepts of classification and remain a matter of debate; for example, the significance of variation in the number of multiple paired muscle scars in oncocerids and discosorids.

Embryonic shells, muscle scars or shell colouration are rarely preserved in the fossil record, whilst precise data relating to age and locality are often missing in specimens from old collections. Therefore any additional material representing exceptionally preserved nautiloids may provide important data for a better understanding of nautiloid taxonomy and evolution. We follow Teichert (1988) in his concept of a subclass, Nautiloidea, which includes the orders Oncocerida, Discosorida, Tarphycerida and Nautilida.

A new oncocerid genus, Euryrizocerina, from the Silurian strata of Bohemia with preserved shell colouration and 


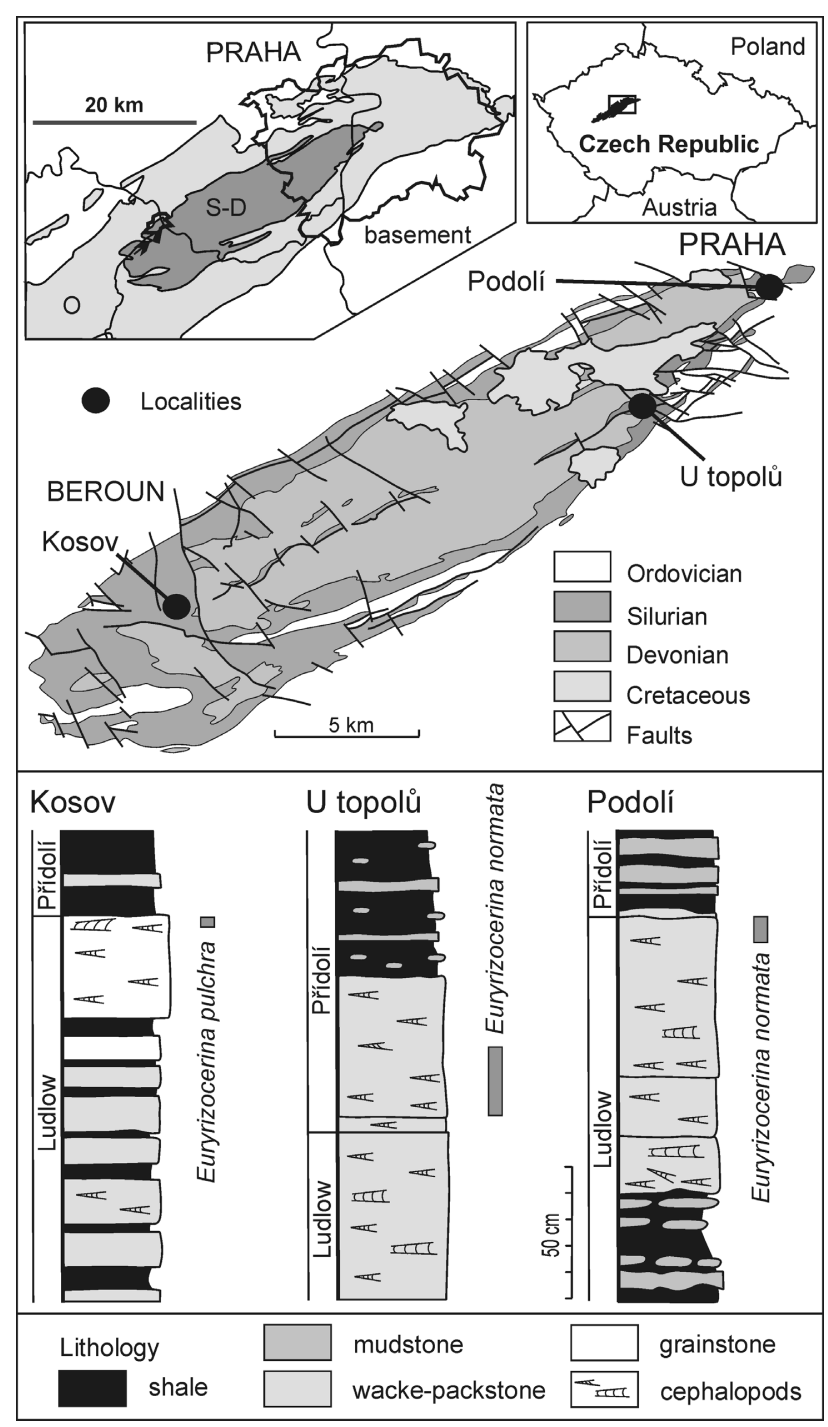

Figure 1. Position of Early Palaeozoic Prague Basin within the Czech Republic (A), Central Bohemia (B), respectively, and detailed map of Prague Synform with location of fossil bearing localities (C). Simplified stratigraphic and lithologic columns are given (B). Data sources: Kosov Quarry after Vokáč (1999), modified; U topolů (unpublished data, Zedník \& Manda); and Podolí (Kř́iž \& Manda, unpublished data).

muscle scars is described in this paper and its taxonomic assignment is discussed. Most of the specimens studied were collected during recent studies of selected sections within the Prague territory and from Kosov Quarry near Beroun, Prague Synform (Fig. 1). A marked change in the character of the muscle scars of Euryrizocerina and its ancestor over a short time interval suggests a high degree of plasticity in the evolution of muscle attachment patterns at least in the Oncocerida and Discosorida.

Terminology. - Morphological terminology is largely adopted from the "Treatise on invertebrate paleontology" (Teichert 1964). The terms height, width and length are used as defined by Stridsberg (1985). Detailed parameters of the curved exogastric shell were not elaborated until now; some terms have been used intuitively. Figure 5 shows the basic parameters we used in descriptions.

The graptolite Zone is used as defined by Štorch (1994, 1995), Křriž (1998) and Manda \& Kříž (2006).

Institutional abbreviations. - Studied specimens are deposited in the Czech Geological Survey, Prague, in the S. Manda collections (prefix CGU SM); National Museum, Prague (prefix NM L); and Museum of Comparative Zoology, Harvard University, Cambridge (prefix MCZ). All specimens, except those figured in Figs 2 and 7F, were coated with ammonium chloride prior to photographing. Specimens with preserved colour pattern were photographed in alcohol.

\section{Colour pattern in nautiloids}

Colour pattern is known only in a small number of Early Palaeozoic nautiloid genera (Kobuk \& Mapes 1989, Turek 2009 and further references herein). Colour patterning was described in the Ordovician tarphycerid Trocholites Conrad, 1838 from Germany (Schuh 1920), in the Silurian oncocerids Octameroceras Hyatt, 1900 from Gotland (Stritsberg 1985) and Rizosceras Hyatt, 1900 from Canada (Foerste \& Savage 1927). Colour patterns in the Devonian Cyrtoceratites Goldfuss, 1833 from Germany were mentioned by Foord (1888) but not illustrated. Sweet \& Leutze (1956) described a shell fragment of a presumed oncocerid with preserved colouration from the Silurian rocks of New York. All other nautiloids with preserved colour pattern are known from the Prague Basin, Bohemia. Several coloured shells were described and illustrated by Barrande (1865-1877) in the Silurian cumulative genera Trochoceras Barrande, 1848, Orthoceras Bruguière, 1792, Cyrtoceras Goldfuss, 1833, and Phragmoceras Broderip, 1839 (in Murchison 1839). Turek $(1990,2004)$ observed colour patterns in some other oncocerids and the discosorid Phragmoceras imbricatum Barrande, 1865, but these specimens have yet to be figured or described in detail. Turek (2009) described well-preserved colour patterns in the Devonian oncocerid Ptenoceras Hyatt, 1894 and Manda \& Turek (2009a) in the Silurian oncocerid Pomerantsoceras Kröger, 2007a.

Almost all Bohemian nautiloid shells with traces of colouration have been obtained from cephalopod limestones that comprise the "condensed" dark grey cephalopod wacke-packstone (Braník type sensu Ferretti \& Kř́ž 1995, Kř́ž 1998). Turek (2009) assumed that low oxygen level on and below the sea-floor, combined with rapid burial and cementation provided suitable conditions for the preservation of colour markings. However, although such 

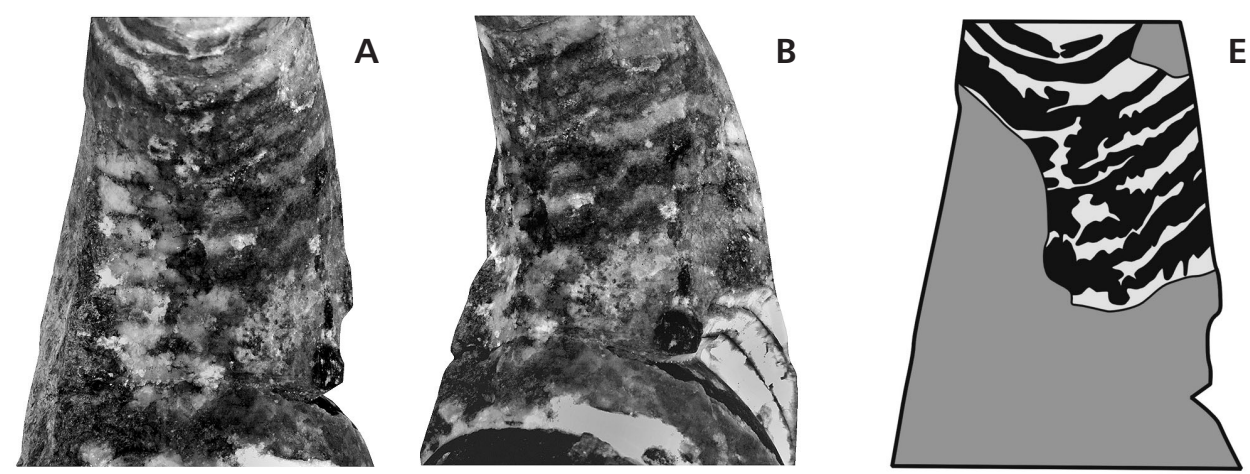

E
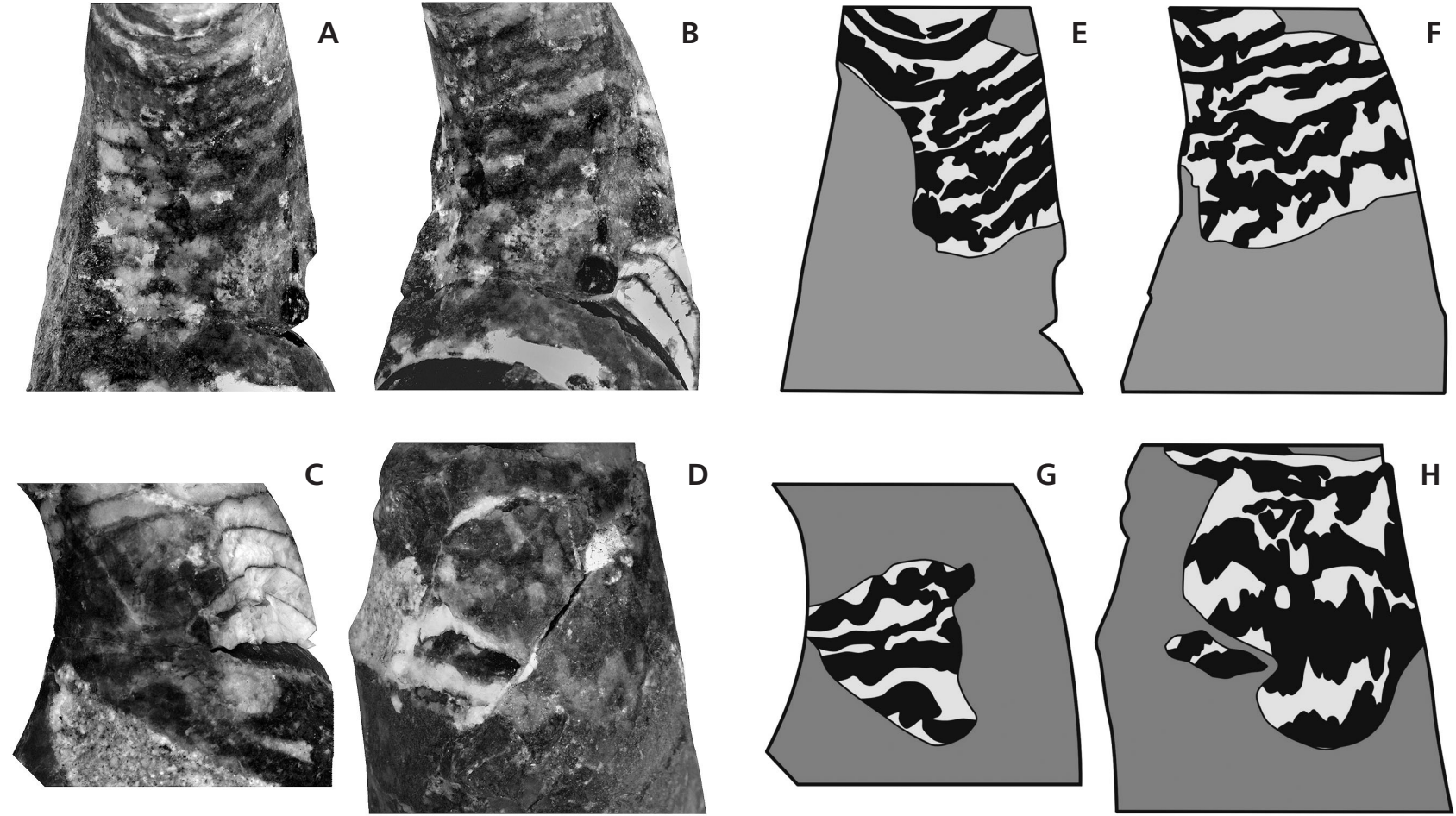

Figure 2. Colour pattern in Euryrizocerina normata sp. nov., photographs (on the left) and sketch drawings (on the right) of the same specimens from Lochkov, U topolů Section, earlier Př́́dolí, Priastiograptus parultimus Zone, Kopanina Formation. • A, B, E, F - CGS SM 379, dorsal and ventolateral views, $\times 2 . \bullet \mathrm{C}, \mathrm{D}, \mathrm{G}, \mathrm{H}-\mathrm{CGS}$ SM 378 , lateral and dorsal views, $\times 1.2$.

conditions characterised the cephalopod limestones of the Braník type in general, coloured shells occur only in a few localities. For example, rich new material, comprising 12 coloured shells (including specimens described below), was obtained from a single bed and limited area in the $\mathrm{U}$ topolů Section. In other parts of the section, as well as in neighbouring sections (Nad ubikacemi, Hvíždalka sections), no coloured shell has been found. This indicates that there are additional factors controling colour preservation that have yet to be recognized.

It is generally accepted that shell colouration in present day Nautilus and Allonautilus, as well as in fossil nautiloids, serves as light screening and camouflage (Stenzel 1964, Cowen et al. 1973, Westermann 1998, Manda \& Turek 2009). Details concerning the intraspecific variability of colour patterns and their evolution remain poorly understood. The exceptionally well-preserved cephalopods from Bohemia are an important source of material with which to resolve these questions, especially in oncocerids (tarphycerids and discosorids with preserved shell colouration are very rare). A further problem is that many of the taxa now thought likely to be oncocerids were originally assigned to Orthoceras and Cyrtoceras by Joachim Barrande (1865-1877). These taxa are poorly known and in need of revision.

Colour patterns in nautiloids take several forms. These include radial bands, transversal undulating lines, zig-zag lines, as well as combinations of these forms (Ruedeman 1921, Foerste 1930a, Teichert 1964, Stridsberg 1985, Kobuk \& Mapes 1989, Turek 2009). High disparity in the pattern of shell colouration itself suggests an adaptive control of shell colouration. Links between shell morphotype, biofacies and colour pattern are poorly understood; although recently such an example was discussed by Manda \& Turek (2009a).

\section{Description of colour pattern in Euryrizocerina and its significance}

Shell colouration is preserved in two specimens of Euryrizocerina normata. In CGS SM 378 (Fig. 2C, D, G, H) the colour pattern is preserved on the dorsal side and in particular the left lateral side of the phragmocone. The colour pattern consists of irregular transverse bands that vary in width between 2 and $4 \mathrm{~mm}$. Neighbouring bands are occasionally connected by narrow longitudinal zones. The course of the bands approximately coincides with the direction of growth lines. In CGS SM 379 (Fig. 2A, B, E, F) the pattern of colouration is preserved in part on the ventral, right lateral, and in particular, the left lateral and dorsal sides of the shell. The colour pattern consists of transverse bands that vary strongly in width ( 2 to $5 \mathrm{~mm}$ ). As with the specimen described previously, the bands are connected by 
narrow longitudinal or slightly oblique zones. In the holotype of Euryrizocerina normata, colouration is poor, but just visible.

Euryrizocerina is the first oncocerid known with a strongly curved shell in which the colour pattern is known. The irregular and pulsating colour bands differ markedly from colour patterns in other oncocerids. The colour pattern in breviconic oncocerids with straight or slightly curved shells (that do not reach the inflexion point, see Fig. 5) that resemble Rizosceras Hyatt, 1900 and Metarizoceras Foerste, 1930b (see Sweet 1964), usually consist of rather regular narrow wavey bands, or zig-zag structures, or a combination of the two (Barrande 1865-1877). Rizosceras and Metarizoceras are regarded as demersal nautiloids living close to the sea-floor with a more or less downwardly oriented aperture. By contrast, Euryrizocerina, with a slender and highly curved shell is interpreted as a nectobenthic, actively swimming nautiloid with a forwardly oriented aperture (see Westermann 1998). Consequently, the difference in the observed colour pattern may be linked to the shell morphotype and thus the mode of life of the organism. Another possibility is that this type of colour pattern is in keeping with the Oonoceratidae, but in actuality only one additional species with a colour pattern that certainly belongs to the latter family is known (mentioned by Turek 1990). The slightly curved "Oonoceras" fraternum (Barrande, 1866) from the late Silurian (late Ludfordian, upper Monograptus latilobus and Monograptus fragmentalis zones) of Bohemia shows similarly pulsating colour bands resembling those of Euryzocerina, but in this case, oblique to the growth lines. It is probable that the difference in the course of the colour bands reflect changes in shell flexure and thus the orientation of the life position of the shell, but a detailed study of "Oonoceras" fraternum is required.

In addition, the preservation of colour markings in three of the seven available specimens of Euryrizocerina normata which possess thin shell walls (max. $0.4 \mathrm{~mm}$ ), suggests that shell thickness is not a significant agent responsible for the preservation of colour in the shells of Nautiloids (see discussion in Turek 2009, p. 500).

\section{Muscle scars in Euryrizocerina: comparison with other Oonoceratidae}

Mutvei (1957) published the first detailed study of muscle scars in Early Palaeozoic cephalopods and discussed muscle scars with regard to the anatomy of nautiloid soft parts and their taxonomic significance. Sweet (1959) described some additional attachment structures and discussed their taxonomic value. Later Mutvei (1964) distinguished three groups of fossil nautiloids on the basis of their shell morphology combined with the number and position of muscle scars - Oncoceratomorphi, Nautilomorphi and Orthoceratomorphi. The Oncoceratomorphi includes the orders Oncoceratida and Discosorida, where 7 to 25 pairs of retractor muscle scars may be developed, the ventral pair being the largest. Nautilomorphi and Orthoceratomorphi probably originated by reduction and further specialisation from cephalopods with multiple paired retractor muscles (compare discussion in Kröger 2007b). A study of muscle scars in Phragmoceras suggested that the number of muscle scar pairs may vary substantially within a clade, and the prominent ventral pair of muscle scars may even be reduced (Manda 2008). The evolution of multiple paired muscle attachments and their function is still poorly understood, but it seems likely to be a promising line of research in the study of the taxonomy and autecology of these groups (see Mutvei 2002, Evans 2005, Kröger \& Mutvei 2005, Manda 2008).

Muscle scars in the Oonoceratidae Hyatt, 1884 are poorly known. Usually there is a narrow annular elevation around the base of the body-chamber with several transversally elongated muscle scars. The ventral pair of scars is usually only slightly larger than the other pairs. The annular elevation is thin on the dorsal side of the body-chamber. A ventral furrow is not known. For examples, see the shells of Oonoceras acinaces (Barrande, 1866) from the late Ludlow, Ludfordian, Monograptus fragmentalis Zone, and Oonoceras aff. acinaces (Barrande, 1866) from the late Přídolí, lower Monograptus transgrediens Zone, of Bohemia (Fig. 3A, B, E, F).

"Oonoceras" fraternum (Barrande, 1866) from the late Ludlow (Ludfordian) of Bohemia (Monograptus latilobus and Monograptus fragmentalis zones) is regarded as the ancestor of the Euryrizocerina line (see below), and exhibits muscle scars that differ from other members of the Oonoceratidae. As with Oonoceras, the annular elevation is situated around the base of the body-chamber, but its width increases from the dorsal to ventral side. Muscle scars are longitudinally elongated and the ventral pair is significantly larger than the others. The ventral furrow is usually well developed (Fig. 3C).

Specimen CGS SM 378 (Euryrizocerina normata) has well-preserved muscle scars (Figs 3D, G and 7C). These scars are rather weak in comparison with the muscle attachments seen in the taxa mentioned above. The annular elevation is shifted aperturally and is broadest on the ventral side but rapidly decreases in width laterally, and on the dorsal side is marked by only a fine ridge. Five pairs of longitudinally elongated muscle scars are developed, and the ventral pair is distinctly larger. The mid-ventral conchal furrow is developed between the ventral pair of muscle scars; its width is greatest at the position of the annular elevation.

The reduction in the width of the annular elevation in Euryrizocerina on the lateral and dorsal surfaces is accom- 

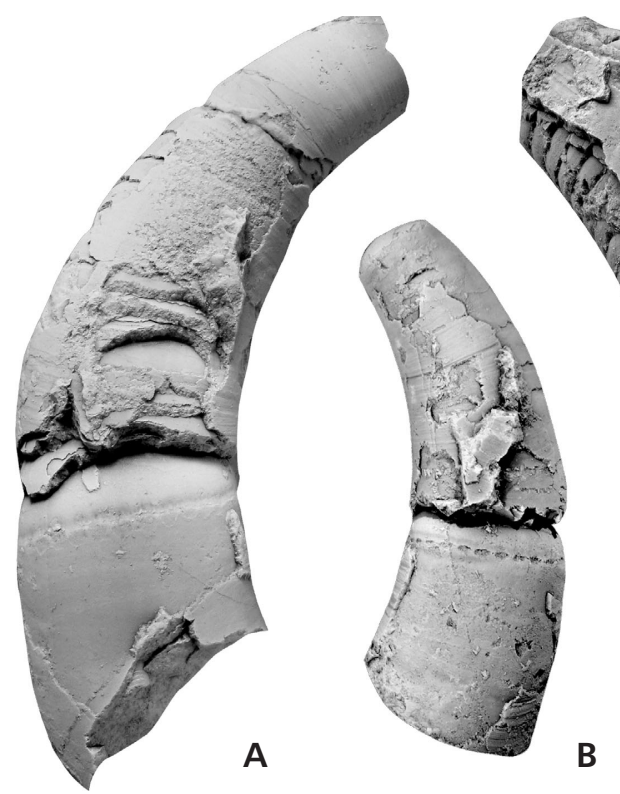
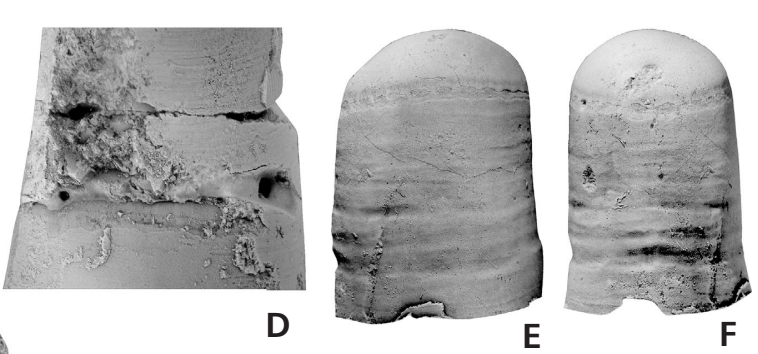

$\mathrm{E}$
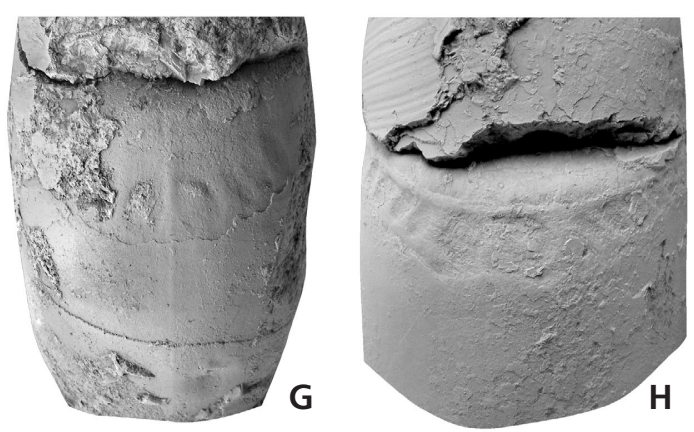

Figure 3. Muscle scars in Euryrizocerina normata and selected Oonoceratidae. $\bullet$ A - Oonoceras acinaces (Barrande, 1866), lateral view, $\times 1.2$; CGS SM 386; Lochkov, Nad ubikacemi Section (unpublished section); Ludlow, Ludfordian, Monograptus fragmentalis Zone, cephalopod limestone biofacies (Kopanina Formation). • B - Oonoceras acinaces (Barrande, 1866), lateral view, × 1; CGS SM 388; Lochkov, Nad ubikacemi Section (unpublished section); Ludlow, Ludfordian, Monograptus fragmentalis Zone, cephalopod limestone biofacies (Kopanina Formation). • C, H - “Oonoceras" fraternum (Barrande, 1866), lateral, $\times 1.1$, and ventral views, × 1.2; CGS SM 387; Praha-Podolí, swimming pool area (unpublished section); Ludlow, Ludfordian, Monograptus fragmentalis Zone, cephalopod limestone biofacies (Kopanina Formation). • D, G - Euryrizocerina normata (Barrande, 1877), dorsal and ventral views, × 1.1; CGS SM 378; Lochkov, U topolů Section; Přídolí, Pristiograptus parultimus Zone, cephalopod limestone (Kopanina Formation). • E, F-Oonoceras aff. acinaces (Barrande, 1866), lateral and ventral views, × 1.5; CGS SM 385; Nová Ves, Bílá skála, bed No. 22 (unpublished section); Přídolí, Monograptus transgrediens Zone, cephalopod limestone with Orthocycloceras fluminese Assemblage (Požáry Formation).

panied by a reduction in the number of muscle scars and an expansion of the ventral muscle scars. The extension of the annular elevation towards the aperture is a distinct feature. These changes in the muscle attachment pattern probably correspond to an increase in the length of the body-chamber and the increased flexure of the shell, which affected the orientation of the shell during life (i.e. the aperture was shifted forward and upwards - Fig. 4).

It is striking that a similar reduction in muscle scars was described in the rutoceratoid (i.e. oncocerid superfamily Rutoceratoidea Hyatt, 1884) Doleroceras resimum Zhuravleva, 1972a from the Eifelian of the Sverlovsk District (see also fig. 7 in Zhuravleva 1972b). In terms of their flexure and general proportions, the shells of Doleroceras bear a strong resemblance to Euryrizocerina. Similarly reduced ventral muscle scars, but shifted more towards the aperture, were described by Turek \& Marek (1986) in the coiled Pragian rutoceratoid Ptenoceras alatum (Barrande, 1865) from Bohemia. The supposed ancestral stock of the rutoceratoids (Silurian-Early Devonian genus Projovellania Hyatt, 1900, see Manda 2001) and the Pragian rutoceratoid Aphyctoceras annulatum (Barrande, 1865) (see Manda \& Turek 2009b, fig. 13b-d) possess annular elevations around the base of the body-chamber, multiple paired muscle scars similar to those seen in Oonoceras.

In summary, there is evidence for convergence in the arrangement of muscle scar attachments in Euryrizocerina, as well as in some openly coiled rutoceratoids, which also reflects convergence in the shell form and consequently the poise of the organism during life. It also documents a high degree of evolutionary plasticity in the muscle attachment patterns in the Oncocerida. In Euryrizocerina, a distinct change in the pattern of muscle attachment took place during the interval (probably less than $0.2 \mathrm{Ma}$ ) of the latest Ludlow, Ludfordian, Monograptus fragmentalis Zone (Fig. 4). The high variability in the number of muscle scars and their shape as well as the convergence observed in the morphotype, indicates that they represent a derived feature under adaptive control rather than an ancestral metamery (see discussion in Kröger 2007b).

It is interesting that in Euryrizocerina and its ancestor "Oonoceras" fraternum the ventral furrow is commonly preserved, while in Oonoceras and allied genera, it has not been observed yet. According to Chirat \& Boletzky (2003, p. 167), the ventral furrow represents a taxonomically unimportant developmental by-product originating "from the inner part of the initial, calcified shell apex, in line with the ventral termination of the central linear depression of the cicatrix" (see also Klug et al. 2008). This means that the ventral furrow is shared by all nautiloids. The taxonomic selectivity in the preservation of the ventral furrow is striking. Moreover, in the holotype of Euryrizocerina pulchra, 


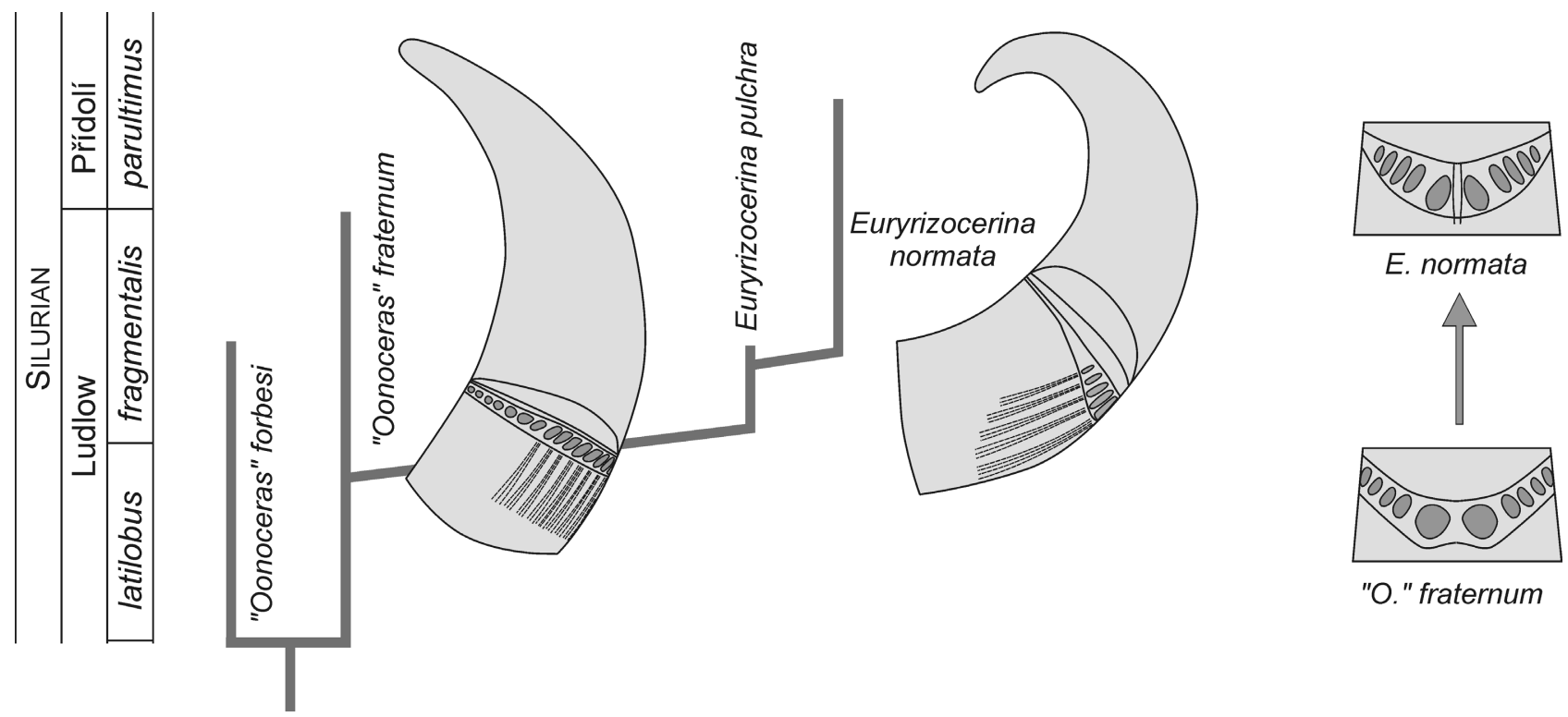

Figure 4. Phylogeny of Euryrizocerina line, evolution of shell form and muscle attachment.

except for the true mid-ventral conchal furrow, a similar furrow is developed on the lateral side close to the dorsum (both in the body-chamber and phragmocone, Fig. 7I, J). Dimensions of both structures are similar, and they both terminate at a similar distance close to the aperture. It may be supposed that such similar structures have the same origin. Nevertheless, according to Chirat \& Boletzky (2003), the mid-ventral furrow arises at the inner ventral termination of the central linear depression of the cicatrix (i.e. embryonic shell). Nautilids exhibit a narrow linear cicatrix. The embryonic shell of oncocerids is poorly known, although there is a circular or elliptical cicatrix with additional radial depressions (Barrande 1877). The lateral furrow may have been originally connected with one of these radial depressions of the cicatrix. Enlargement of the conchal furrow within the annular elevation of Euryrizocerina may suggest that it was involved in some way with the musculature (Fig. 3G). It may be significant that the conchal furrow separates the ventral pair of muscle scars.

\section{Systematic palaeontology}

Subclass Nautiloidea Agassiz, 1847

Order Oncocerida Flower, 1950

Family Oonoceratidae Flower, 1942

Diagnosis of the family. - Oncocerids with an exogastrically cyrtoconic shell; shell curvature varies only slightly within a species; siphuncle without deposits, marginal, in later ontogenetic stages slightly sub-marginal; phragmocone chambers are low; suture with broad lateral lobes; hyponomic sinus usually well developed; body-chamber rela- tively short, slightly longer than wide; cross-section laterally compressed. Embryonic shell is cup-like, early shell less curved than adult shell (after Manda \& Turek 2009).

Discussion. - Barrande (1865-1877) described many Silurian oncocerids with an exogastrically curved shell and a thin siphonal tube lacking intrasiphonal deposits. These taxa are in need of revision. They are usually placed in $\mathrm{Oo}$ noceras or allied genera (Hyatt 1884, Gnoli \& Serventi 2006). Recent examination of new collections from single beds (i.e. focusing on variability in individual palaeopopulations) show that these taxa exhibit relatively low intraspecific variability in shell flexure, cross-section, inner structure and muscle scars. By contrast, the shell sculpture seems to be rather variable in certain species e.g. "Oonoceras" haueri (Barrande, 1886), "Oonoceras" patulum (Barrande, 1866) and Oonoceras acinaces (Barrande, 1866). Differences in the muscle attachment scar pattern between Oonoceras acinaces and allied forms and "Oonoceras" fraternum (noted above) may indicate that there are two distinct groups within the Oonoceratidae, but a detailed study is required.

The vast majority of Silurian Oonoceratidae from Bohemia possess shell with compressed cross-section. Only a few species possess a circular cross-section as is seen in Euryrizocerina. Cyrtoceras obesum Barrande, 1866 has a slightly curved exogastric shell with a circular cross section. The length of the body-chamber is approximately equal to, or slightly greater than the shell height at the aperture. Shell morphology is similar to that of the type species of Euryrizoceras Foerste, 1930 from the middle Silurian of Illinois (Sweet 1964). Barrande (1866, 1877) described 

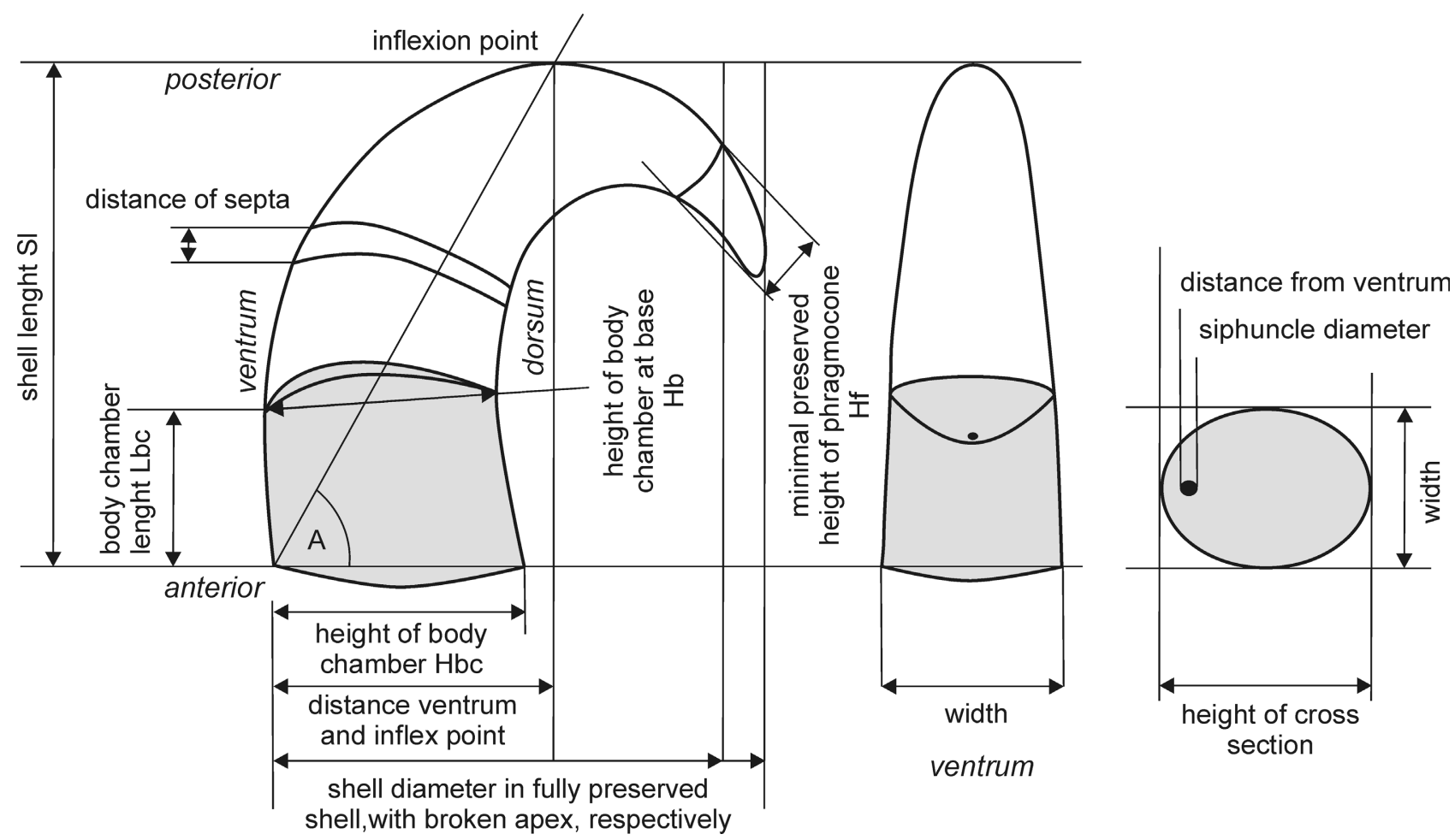

Figure 5. Shell dimensions of a cyrtocone shell: lateral and ventral views, and cross-section.

this long ranging species from the early Wenlock, Monograptus belophorus Zone (St. Iwan, pl. 521, refigured here in Fig. 6), early Ludlow, Gorstian, Colonograptus colonus Zone (Butowitz e1, pl. 114), late Ludlow, Ludfordian, Monograptus fragmentalis Zone (Kozorz, pl. 508) and probably late Přídolí (Novy Mlyn, pl. 114). Euryrizoceras obesum strongly resembles Euryrizocerina, but differs in the higher angle of expansion, shorter body chamber and less curved shell. In addition, the muscle attachment scars consist of multiple paired muscle scars around the base of the body chamber, which on the dorsal side are missing where the annular elevation narrows (Fig. 6). Consequently, Euryrizocerina and Euryrizoceras are not considered to be closely related. It seems likely that there are many convergences in shell form in the Oncocerida. Muscle scars may be useful in the recognition of such convergences.

Genera included. - Euryrizocerina gen. nov. (Silurian), Oonoceras Hyatt, 1884 (Silurian, earlier Devonian), Pomerantsoceras Kröger, 2007 (latest Ordovician, Silurian), Pleziorizoceras Chen, 1981 (middle Silurian), Shuranoceras Barskov, 1959 (Silurian).

\section{Genus Euryrizocerina gen. nov.}

Type species. - Cyrtoceras normatum Barrande, 1877. Latest Ludlow, early Přídolí of Bohemia (Prague Basin).
Etymology. - The diminutive form, derived from the generic name Euryrizoceras.

Diagnosis. - Strongly curved exogastric cyrtoconic nautiloid with circular or slightly depressed cross-section, body chamber distinctly longer than wide, length of body chamber about half the shell length, shell diameter greater than shell length in fully grown shell, muscle scars positioned on ventrum, reduced; regular growth lines.

Discussion. - Oonoceras acinaces (Barrande, 1866), the type species of Oonoceras, differs from the new genus in having a less curved and longer shell, the degree of shell flexure decreases during growth of the shell. The shell cross-section is strongly depressed, and the annular elevation is well developed around the base of the body chamber. The septa are relatively deep, and the suture more oblique, with distinct lateral saddles. The growth lines are rather irregular, and in large shells form irregular flanges. Oonoceras acinaces ranges from the latest Ludlow (Ludfordian, Monograptus latilobus and $M$. fragmentalis Zone) to the early Přídoli (Pristiograptus parultimus Zone) of the Prague Basin, and is thus coeval with Euryrizocerina. This further suggests that separate phylogenetic lines are represented.

Euryrizocerina pulchra sp. nov. shares similar shell flexure and relatively long body chamber with E. normata, but differs in its more elaborate growth lines and higher angle of expansion. "Oonoceras" fraternum (Barrande, 

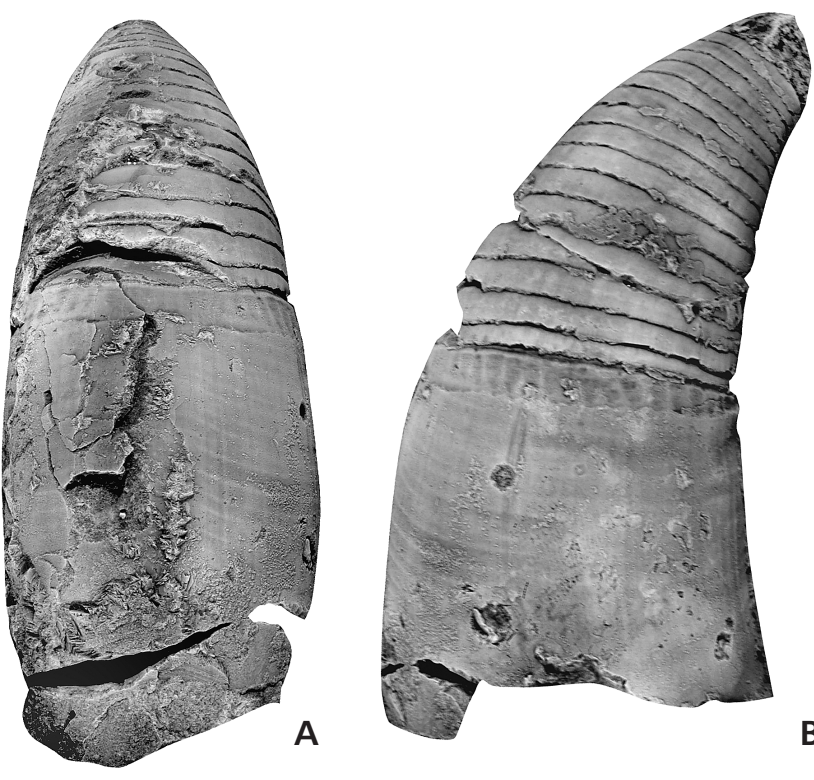

B

1866) differs from Euryrizocerina pulchra sp. nov. in having a higher angle of shell expansion, a short body chamber, a more compressed conch cross-section, and in particular, a much less curved shell; both species have a similar pattern of growth lines. In summary, "Oonoceras" fraternum is considered to be the ancestor of Euryrizocerina pulchra, from which E. normata diverged. The sucession of these species in the fossil record corresponds well with their assumed phylogeny.

"Oonoceras" fraternum and the closely related "Oonoceras" forbesi (Barrande, 1866) appeared in the late Monograptus latilobus Zone (Ludlow, Ludfordian); they belong to the enriched cephalopod assemblages that originated during the recovery that took place after the Kozlowskii extinction event. This event caused a drastic decline in the cephalopod faunas of the Prague Basin and no nautiloids are known from the early Monograptus latilobus Zone (Manda, unpublished data). Most of the nautiloids appearing in the late Monograptus latilobus Zone are immigrants from lower latitude carbonate platforms. The coiled tarphycerid Boionautilus Turek, 2008 is a well-documented example (Turek 2008). Consequently, tracing the phyletic links of these immigrants is a problematic exercise.

"Cyrtorizoceras" fosteri (Hall, 1860) from the early Ludlow Series, Port Byron Dolomite, Illinois (see also Foerste 1930b) strongly resembles "Oonoceras" forbesi in its shape and the dimensions of the conch, nevertheless, detailed comparison is impeded by the poor condition of preservation in the dolomite. Still un-described species strongly resembling "Oonoceras" forbesi also occur in the Wenlock and Ludlow rocks of Gotland (collection of The Swedish Museum of Natural History).

Species included. - Euryrizocerina normata (Barrande,

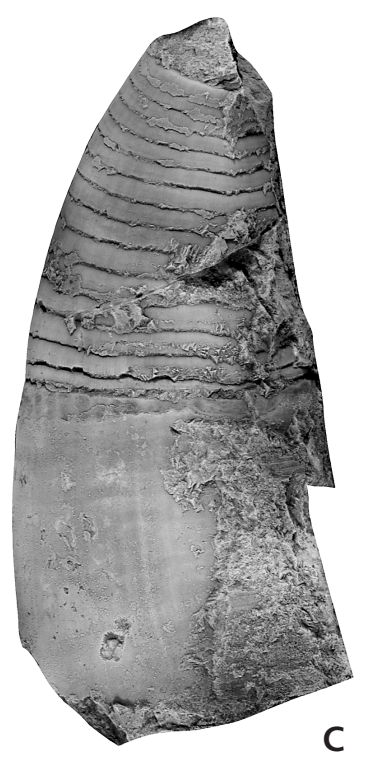

Figure 6. An example of muscle scars in Euryrizoceras obesum (Barrande, 1866), an original specimen figured by Barrande (1877, pl. 521, figs 10-13), locality Environs de St. Iwan e2 ("vicinity of Svatý Jan pod Skalou Village"), based on the character of the rock, the specimen comes from U elektrárny Section (old collector pits), Monograptus. belophorus Zone, middle Sheinwoodian, Wenlock, brachiopodtrilobite limestone, Motol Formation (see Havlíček \& Štorch 1990, Havlíček 1995). Ventral, lateral and dorsal views, all × 0.7; MCZ 173057, Šáry’s Collection.

1877) and Euryrizocerina pulchra sp. nov. from the late Silurian of Bohemia.

Euryrizocerina normata (Barrande, 1877)

Figures 2, 3D, G, 7A-H

1877 Cyrtoceras normatum Barr.; Barrande, p. 159, pl. 528, figs $22-24$.

Holotype. - Holotype by monotypy is specimen NM L 21830 figured by Barrande (1877, pl. 528, figs 22-24). Late Silurian (most probably early Přídolí, on the evidence of the mode of preservation), Kopanina Formation, locality Lochkov e2 (i.e. Praha-Lochkov).

Material. - The holotype and six additional specimens collected during recent field studies by the authors and Ladislav Zedník; CGS SM 378, 379 (Praha-Lochkov, U topolů Section, earliest Přídolí, Pristiograptus parultimus Zone), CGS SM 380, 381 (Praha-Podolí, swimming pool, latest Ludlow (Ludfordian), Monograptus fragmentalis Zone), and CGS SM 382, 383 (Praha-Lochkov, "Pod borovicemi" Section, latest Ludlow (Ludfordian, Monograptus fragmentalis Zone).

Diagnosis. - Euryrizocerina with circular cross-section, subventral siphuncle and fine growth lines.

Descriptions. - An exogastric cyrtocone with a circular cross-section and a low angle of expansion. The septa are parabolic with a maximum depth coinciding with the shell axis. The sutures straight and oblique and oblique to the normal of the conch axis. The distance between septa in- 

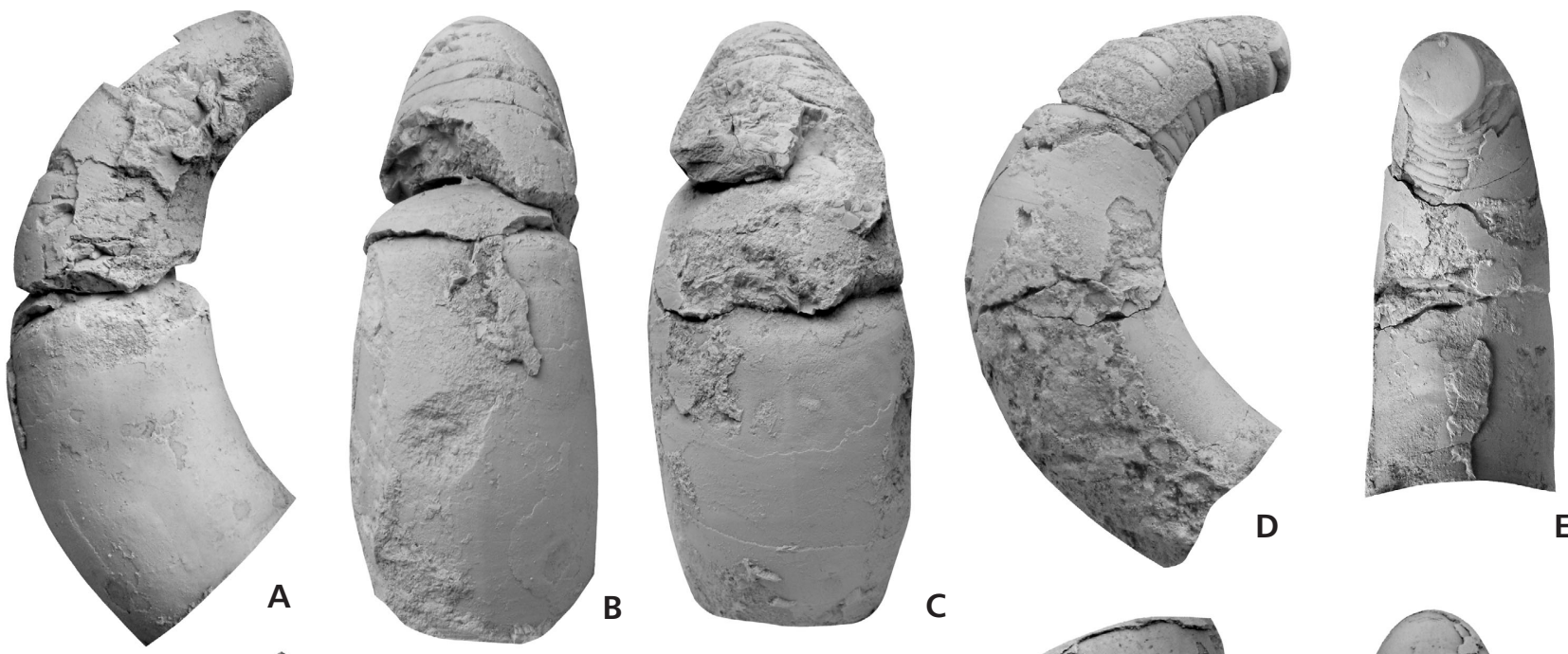

E
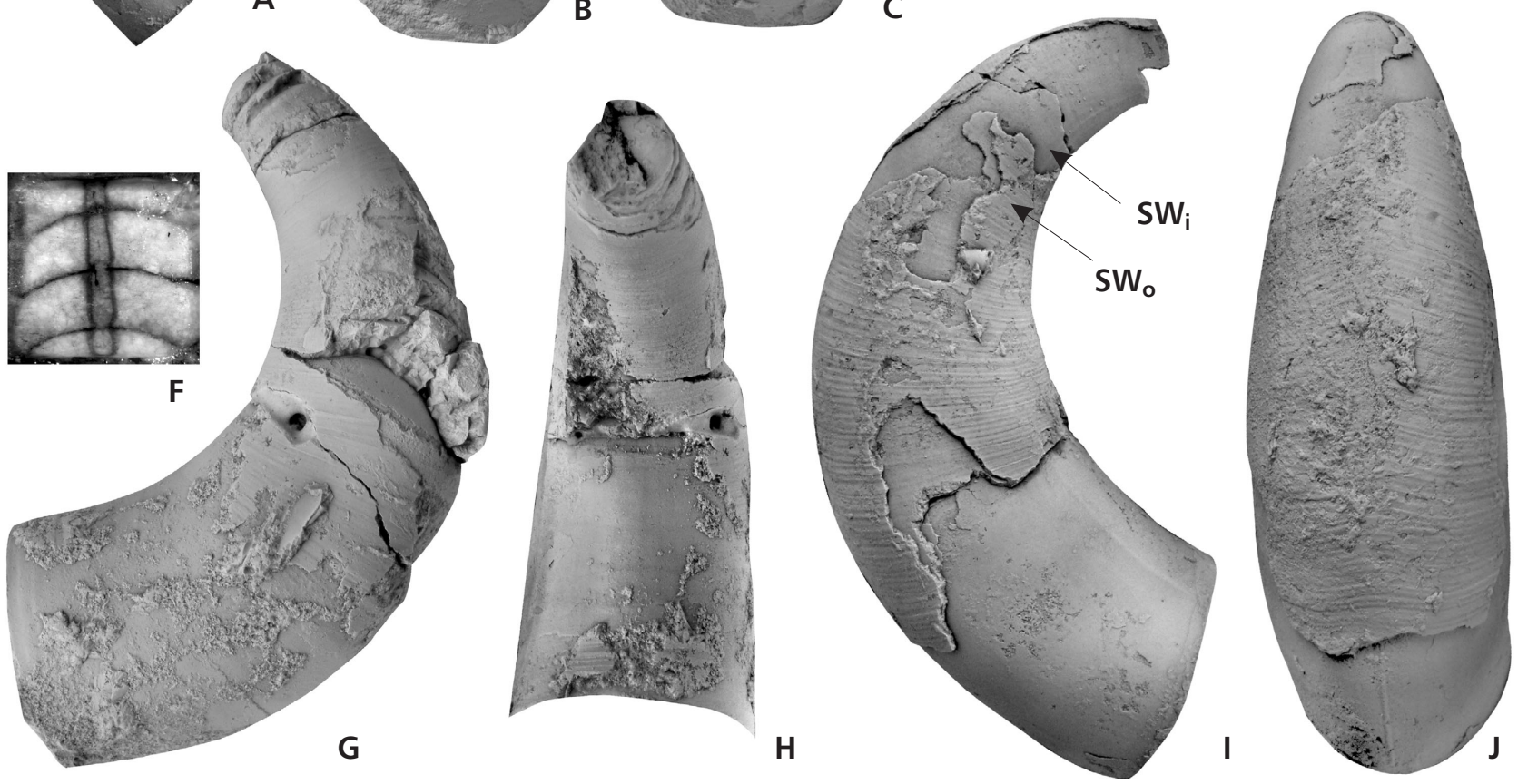

Figure 7. A-H - Euryrizocerina normata sp. nov. $\bullet$ A, B, F-NM L 21830, lateral and ventral views, $\times 1$, and detail of siphuncle, $\times 2.6$; holotype figured by Barrande (1877) in pl. 528 as figs 22-24, late Silurian (most probably early Přídolí, on the basis of the mode of preservation), Kopanina Formation, locality Lochkov e2 (i.e. Praha-Lochkov). • C, G, H - CGS SM 378, ventral, × 1, lateral and dorsal views, × 0.9; Lochkov, U topolů Section; Př́idolí, Pristiograptus parultimus Zone, cephalopod limestone (Kopanina Formation). $\bullet$ D, E - CGS SM 379, lateral, $\times 0.9$, and dorsal views, $\times 0.8$; Lochkov, U topolů Section; Př́dolí, Pristiograptus parultimus Zone, cephalopod limestone (Kopanina Formation). $・$ I, J - Euryrizocerina pulchra sp. nov., CGS SM 384, lateral and ventral views, $\times 0.8$; Kosov Quarry near Beroun, latest Ludlow, Monograptus fragmentalis Zone. Arrows indicate the two layers of the shell wall: $\mathrm{sw}_{\mathrm{i}}$ (inner layer) and $\mathrm{sw}_{\mathrm{o}}$ (outer layer).

creases from $c a 1 \mathrm{~mm}$ (at a shell height of $10 \mathrm{~mm}$ ) to $c a$ $3 \mathrm{~mm}$ (at a shell height of $27 \mathrm{~mm}$ ). The siphuncle is thin and subventral in position; its diameter increases from $0.5 \mathrm{~mm}$ (at a shell height of $10 \mathrm{~mm}$ ) to $1.5 \mathrm{~mm}$ (at a shell height of $31 \mathrm{~mm}$ ). The septal necks are very short, and the connecting rings thin and only moderately vaulted. The body-chamber is relatively long. Four pairs of muscle scars are present, the ventral pair being the largest. The muscle scars are elongated in the direction parallel to the shell axis on the lateral side of the shell. A narrow, but distinct ventral furrow may be seen in the holotype. The aperture is open with a straight, well-developed hyponomic sinus. In one specimen, the aperture becomes slightly contracted. Fine, dense growth lines are present. These are almost straight and oblique to the normal of the conch axis. Shallow and broad ventral lobes are formed by the growth lines, and some growth lines are slightly more accentuated than others. The shell is relatively thin, reaching a maximum thickness of $0.4 \mathrm{~mm}$ (at a shell height of $33 \mathrm{~mm}$ ).

Dimensions. - Sl - shell length, Lbc - length of body chamber, $\mathrm{Hbc}$ - height of body chamber at aperture, $\mathrm{Hb}-$ 
height of body chamber at base, Hf - minimal preserved height of phragmocone, Sdia - shell diameter, A - angle between apertural line and point inflexion; see Fig. 5. All measurements except $\mathrm{A}$ are in millimetres.

\begin{tabular}{lccccccc}
\hline Specimen & Sl & Lbc & Hbc & Hb & Hf & Sdia & A \\
\hline NM L 21830 & 43.5 & 31.5 & 21 & 19.5 & 9 & 48.5 & $c a 50^{\circ}$ \\
SM 378 & 56 & 41 & 27 & 25 & 10.5 & 61 & $c a 50^{\circ}$ \\
SM 379 & 49 & 34 & 22.5 & 24 & 9 & 55 & $c a 55^{\circ}$ \\
SM 380 & - & - & - & 21.5 & 16 & - & - \\
SM 381 & 63 & 49 & 31.5 & 28.5 & 17.5 & 60 & - \\
SM 382 & 59 & 35 & 28 & 24.5 & 13 & 52 & $c a 55^{\circ}$ \\
SM 383 & 48 & 42 & 25 & 24 & 16 & 58.5 & $c a 55^{\circ}$ \\
\hline
\end{tabular}

Occurrence. - Late Silurian of Bohemia, latest Ludlow, Ludfordian (Monograptus fragmentalis Zone) and earlier Přídolí (Pristiograptus parultimus Zone), Prague Basin, upper part of the Kopanina Formation.

Praha-Lochkov, U topolů Section (see Svoboda \& Prantl 1950), earliest Přídolí, Pristiograptus parultimus Zone, facies of dark-grey cephalopod limestone, accompanied by a fauna consisting of common cephalopods (Arionoceras sp., Boionautilus tyrannus, Cinctoceras sp., Kopaninoceras sp., Mandaloceras sp. div., Michelinoceras michelini, Oonoceras div. sp., Ophioceras simplex, Parakionoceras originale, Peismoceras optatum, Pseudocycloceras sp., Umbeloceras sp. div.), bivalves (Cardiola conformis Community sensu Křǐž 1999), less common gastropods (Pleurorima a.o.), trilobites (Cromus), and graptolites.

Praha-Lochkov, "Pod borovicemi" Section, an undescribed section, natural outcrops in the upper part of the Kopanina Formation on a south-inclined slope in Radotín Valley, $1143 \mathrm{~m} \mathrm{SW}$ from the bus station in Praha-Lochkov, latest Ludlow, Ludfordian, Monograptus fragmentalis Zone, grey weathering cephalopod limestone with a poorly preserved fauna (P. normata and Arionoceras sp., Kopaninoceras sp., Kosovoceras sandbergeri, Michelinoceras michelini, and unidentified cardiolid bivalves).

Praha-Podolí, swimming pool, an unpublished section, latest Ludlow (Ludfordian), a $20 \mathrm{~cm}$ thick bed just below base of Př́dolí (identified by Cardiola bohemica accumulations and Pristiograptus parultimus), Monograptus fragmentalis Zone (former Prionopeltis archiaci Horizon). Facies of dark-grey cephalopod limestone. E. normata occurs together with common cephalopods (Arionoceras sp., Kopaninoceras sp., Kosovoceras sandbergeri, Kosovoceras nodosum, Lechritrochoceras degener, Mandaloceras sp. div., Michelinoceras michelini, Oonoceras div. sp., Ophioceras simplex, Ovocerina sp., Parakionoceras originale, Pseudocycloceras sp., Umbeloceras sp. div.), bivalves (Cardiola conformis Community sensu Kř́̌ž 1999), rare gastropods, bryozoans, graptolites, and trilobites.

\section{Euryrizocerina pulchra sp. nov.} Figure 7I, J

Etymology. - Derived from the Latin adjective pulchra (beautiful) referring to the excellent preservation of the holotype and elegant shell design.

Holotype. - CGS SM 384 figured as Fig. 7I, J. From Kosov Quarry near Beroun, latest Ludlow, Ludfordian, Monograptus fragmentalis Zone.

Diagnosis. - Euryrizocerina with slightly compressed cross-section and regular prominent growth lines.

Descriptions. - The holotype is an almost complete exogastric, slightly expanding, longiconic cyrtoconic shell. Only the apical part of the shell is missing. The length of the preserved portion of shell is $65 \mathrm{~mm}$, and the maximum shell height is $30 \mathrm{~mm}$, with a width of $28.5 \mathrm{~mm}$. The cross-section is slightly compressed and the ratio of shell height to width decreases during growth from 1.2 to 1.05 . The septa are concave and the suture oblique with very shallow lateral saddles. The distance between septa varies from 2.5 to $3 \mathrm{~mm}$. A siphuncle has not yet been observed. The body-chamber is relatively long $(40 \mathrm{~mm})$ and the base of the body-chamber has a height of $31 \mathrm{~mm}$ and a width of $27 \mathrm{~mm}$. A narrow $(0.9 \mathrm{~mm})$ ventral furrow is visible on the body-chamber; it disappears just before the aperture. A similar, but less distinct furrow is visible on the right lateral side of the body-chamber, close to the dorsum. The aperture is open and straight, with a well-developed hyponomic sinus. Growth lines are regular and straight. They are oblique to the normal of the conch axis and a prominent shallow but broad hyponomic sinus is present. The distance between growth lines in the adult portion of the shell is $c a$ $1 \mathrm{~mm}$. The maximum thickness of the shell is about $1.2 \mathrm{~mm}$. The shell wall consists of two layers, an outer, thicker layer which carries growth sculpture, whilst the inner, thinner layer has a smooth surface (see Fig. 7I).

Occurrence. - The holotype was collected from the uppermost part of the cephalopod limestone bank, Monograptus fragmentalis Zone, latest Ludlow, Ludfordian, in new Kosov Quarry, $1^{\text {st }}$ level, south wall, close to section number 783 (actually quarried out) measured by Kř́ž (1992, p. 60, fig. 44). The section was recently re-measured by Vokáč (1999). These cephalopod limestones consist of rusty, coarse pack-grainstone. The exceptional preservation of the holotype is caused by fossilisation in a fine rusty mudstone inside the body-chamber of a large pseudorthocerid (see Turek 1974). The accompanying fauna consists of a diverse cephalopod assemblage (Arionoceras sp., Dawsonocerina caelebs, Geisonoceras rivale, Hexameroceras panderi, Kopanonoceras sp., Kosovoceras nodosum, Kosovoceras 
sandbergeri, Lyecoceras neptunicum, Oonoceras acinaces, "Oonoceras" forbesi, Ophioceras simplex, Oxygonioceras sp., Plagiostomoceras sp., "Sactoceras" pellucidum, Tetrameroceras sp.; see Turek 1992), with less common bivalves (e.g., Cardiola conformis), rugose and tabulate corals, gastropods, and trilobites (e.g., Prionopeltis archiaci) occur rarely. The cephalopod fauna from the limestone bank corresponds with the cephalopod assemblage developed in several sections in the Prague territory in the lower part of the Monograptus fragmentalis Zone (former Prionopeltis archiaci Horizon). It is probable that the upper bedding plane of the cephalopod limestone bank in Kosov Quarry coincides with the Ludlow-Přídolí boundary and represents a condensed surface and a hiatus.

\section{Acknowledgments}

The research was funded by GA ČR (Czech Science Foundation) projects 205/09/0703 (to Š.M.), 205/09/0260 (to V.T.) and Ministry of Culture project MK 00002327201 (to V.T.). The authors thank journal referees David H. Evans and Radvan J. Horný for critical reading of the manuscript and improvements to the English, and Jiří Frýda for technical help with photographs. The authors thank Jessica Cundiff (Museum of Comparative Zoology, Harvard) for providing the material used in this study from Šáry's collection.

\section{References}

AGASSIZ, L. 1847. An introduction to the study of Natural history, in a series of lectures delivered in the hall of the College of Physicians and Surgeons. 58 pp. Kessinger Publishing, New York.

BARRANDE, J. 1865-1877. Systême silurien du Centre de la Bohême, I ère partie: Recherches Paléontologiques, vol. II, Classe de Mollusques, Ordre des Céphalopodes. 1865. ser. 6, pl. 1-107; 1866. ser. 7, pl. 108-244; 1867. ser. 1, 712 pp.; 1868. ser. 8, pl. 245-350; 1870. ser. 2, 266 pp., ser. 9, pl. 351-460; 1874. ser. 3, 804 pp.; 1877. ser. 4, 742 pp., ser. 5, 743 pp., supplement 1, 297 pp., supplement 2, pl. 461-544. Privately published, Prague \& Paris.

BARSKOV, I.S. 1959. New Silurian nautiloids from South Fergana. Paleontologicheskii Zhurnal 3, 55-60. [in Russian]

BRuguiÈRE, J.G. 1792. Encyclopédie méthodique. Histoire naturelle des vers 1, pt. 2, 85-132. Panckoucke, Paris.

CONRAD, T.A. 1838. Report on the Palaeontological Department of the Survey (New York). New York State Geological Survey, Annual Report 2, 107-119.

CHEN, J. 1981. In CHEN, J., LIU, G. \& CHEN, T. 1981. Silurian nautiloid faunas of Central and Southwestern China. Memoires of Nanjing Institut of Geology and Palaeontology 13, 1-104.

CHIRAT, R. \& VON BOLETZKY, S. 2003. Morphogenetic significance of the conchal furrow in nautiloids: Evidence from early embryonic shell development of Jurassic Nautilida. Lethaia 36, 161-170. DOI 10.1080/00241160310004602

Cowen, R., Gertman, R. \& Wiggett, G. 1973. Camouflage patterns in Nautilus, and their implications for cephalopod paleobiology. Lethaia 6, 201-214.

DOI $10.1111 / \mathrm{j} .1502-3931.1973 . t b 01193 . x$

DZIK, J. 1984. Phylogeny of the Nautiloidea. Palaeontologia Polonica 45, 1-255.

Evans, D.H. 2005. The Lower and Middle Ordovician cephalopod faunas of England and Wales. Monograph of the Palaeontological Society, 1-81.

FERRETTI, A. \& KŘíž, J. 1995. Cephalopod Limestone Biofacies in the Silurian of the Prague Basin, Bohemia. Palaios 10(3), 240-253. DOI 10.2307/3515255

Flower, R.H. \& KuMMEL, B. 1950. A classification of the Nautiloidea. Journal of Paleontology 24, 604-616.

FLOWER, R.H. 1942. An arctic cephalopod faunule from the Cynthiana of Kentucky. Bulletins of American Paleontology 27, 1-41.

FOERSTE, A.F. 1930a. The colour patterns in fossil cephalopods and brachiopods, with notes on gastropods and pelecypods. Contributions from the Museum of Palaeontology, Michigan 3(6), 109-150.

FOERSTE, A.F. 1930b. Port Byron and other Silurian cephalopods. Denison University Bulletin, Journal of the Scientific Laboratories 23, 1-110.

Foerste, A.F. \& SAVAGE, T.E. 1927. Ordovician and Silurian cephalopods of the Hudson Bay area. Journal of the Scientific Laboratories Denison University Bulletin 22, 1-107.

FOORD, A.H. 1888. Catalogue of the fossil cephalopoda in the British Museum (natural history). Part of the suborder Nautiloidea consisting of the families orthoceratidae, endoceratidae, actinoceratidae, gomphoceratidae, ascoceratidae, poterioceratidae, cyrtoceratidae and supplement. $344 \mathrm{pp}$. British Museum of Natural History, London.

GNOLI, M. \& SERVENTI, P. 2006. A further oncocerid nautiloid from the Upper Silurian of Southwest Sardinia. GeoAlp 3(3), 3-8.

HAVLÍČEK, V. 1995. New data on the distribution of brachiopods in the Motol and lowest Kopanina Formations (Wenlock, lower Ludlow, Prague Basin, Bohemia). Věstník Českého geologického ústavu 70(4), 47-63.

HAVLÍČEK, V. \& ŠTORCH, P. 1990. Silurian brachiopods and benthic communities in the Prague Basin (Czechoslovakia). Rozpravy Ústředního ústavu geologického 48, 1-275.

HyatT, A. 1883-1884. Genera of fossil cephalopods. Proceedings of the Boston Society of Natural History 22, 273-338.

HyATT, A. 1894. Phylogeny of an Acquired characteristic. Proceedings American Philosophical Society 32, 349-647.

HyATT, A. 1900. Cephalopoda, 502-592. In ZiTTEL, K.A. \& EASTMAnN, C.R. (eds) Textbook of Palaeontology, vol. 1. Macmillan and Co., Boston.

Klug, C., MEYER, E.P., Richter, U. \& KoRn, D. 2008. Soft-tissue imprints in fossil and Recent cephalopod septa and septum formation. Lethaia 41, 477-492. DOI $10.1111 / \mathrm{j} .1502-3931.2008 .00100 . x$

KOBLUK, D.R. \& MAPES, R.H. 1989. The fossil record, function and possible origins of shell color patterns in Paleozoic marine invertebrates. Palaios 4, 63-85. DOI 10.2307/3514734

KŘíž, J. 1992. Silurian Field Excursions: Prague Basin (Barrandian), Bohemia. National Museum of Wales, Geological Series $13,1-110$.

KŘíž, J. 1998. Recurrent Silurian-lowest Devonian cephalopod limestones of Gondwanan Europe and Perunica, 183-198. In LANDING, E. \& JOHnSOn, M.E. (eds) Silurian cycles: Linkages of dynamic stratigraphy with atmospheric, oceanic, and tectonic changes. New York State Museum Bulletin 491. 
KŘíž, J. 1999. Bivalvia dominated communities of Bohemian type from the Silurian and Lower Devonian carbonate facies, 225-248. In BouCOT, A.J. \& LAWsOn, J.D. (eds) Final report, project Ecostratigraphy. Paleocommunities: A case study from the Silurian and Lower Devonian. Cambridge University Press, Cambridge.

KRÖGER, B. 2007a. Concentrations of juvenile and small adult cephalopods in the Hirnantian cherts (Late Ordovician) of Porkuni, Estonia. Acta Palaeontologica Polonica 52, 591-608.

KRÖGER, B. 2007b. Some lesser known features of the ancient cephalopod order Ellesmeroceratida (Nautiloidea, Cephalopoda). Palaeontology 50(3), 565-572. DOI $10.1111 / \mathrm{j} .1475-4983.2007 .00644 . \mathrm{x}$

KRÖGER, B. \& MUTVEI, H. 2005. Nautiloids with multiple paired muscle scars from Lower-Middle Ordovician of Baltoscandia. Palaeontology 48(4), 781-791. DOI $10.1111 / j .1475-4983.2005 .00478 . x$

MANDA, Š. 2001. Some new or little known cephalopods from the Lower Devonian Pragian carbonate shelf (Prague Basin, Bohemia) with remarks on Lochkovian and Pragian cephalopod evolution. Journal of the Czech Geological Society 46(3-4), 269-286.

MANDA, S. 2008. Palaeoecology and palaeogeographic relations of the Silurian phragmoceratids (Nautiloidea, Cephalopoda) of the Prague Basin (Bohemia). Bulletin of Geosciences 83(1), 39-62. DOI 10.3140/bull.geosci.2008.01.039

MANDA, Ś. \& KŘİŽ, J. 2006. Environmental and biotic changes of the subtropical isolated carbonate platforms during Kozlowskii and Lau events (Prague Basin, Silurian, Ludlow). GFF 128, 161-168. DOI 10.1080/11035890601282161

MANDA, Š. \& TUREK, V. 2009a. Minute Silurian oncocerid nautiloids with unusual colour patterns. Acta Palaeontologica Polonica 54, 503-512.

MANDA, Š. \& TUREK, V. 2009b. Pragian Rutoceratoidea Hyatt, 1884 (Nautiloidea Oncocerida) from the Prague Basin. Bulletin of Geosciences 84(1), 127-148.

MURCHISON, R.I. 1839. The Silurian system founded on geological researches in the counties of Salop, Hereford, Padnor, with descriptions of the coal fields and overlying Formations. Part 1. $768 \mathrm{pp}$. London.

MuTVEI, H. 1957. On the relations of the principal muscles to the shell in Nautilus and some fossil nautiloids. Arkiv for Mineralogi och Geologi 2, 219-254.

MUTVEI, H. 1964. Remarks on the anatomy of Recent and fossil Cephalopoda. Stockholm Contributions on Geology 11, 79-102.

MUTVEI, H. 2002. Nautiloid systematics based on siphuncular structure and position of muscle scars. Abhandlungen der Geologischen Bundesanstalt 57, 379-392.

RUEDEMANN, R. 1921. On color bands in Orthoceras. Bulletin New York State Museum 227, 63-130.

SCHUH, F. 1920. Farbreste auf der Schalenoberfläche eines Trocholites. Zeitschrift der Deutschen Gesellschaft für Geowissenschaften 72(1920), 181-185.

STENZEL, H.B. 1964. Living Nautilus, 59-93. In MoORE, R.C. (ed.) Treatise on Invertebrate Paleontology, Part K, Mollusca 3. The Geological Society of America \& The University of Kansas Press, Lawrence.

STRIDSBERG, S. 1985. Silurian oncocerid cephalopods from Gotland. Fossils and Strata 18, 1-65.

SvOBODA, J. \& PRANTL, F. 1950. Stratigraficko-tektonická studie okolí lomu „Cikánka“ v radotínském údolí. Sborník Státního geologického ústavu, Oddíl geologický 17, 105-139.
SWEET, W.C. 1959. Muscle attachment impressions of some Paleozoic nautiloid cephalopods. Journal of Paleontology 33, 293-305.

SWEET, W.C. 1964. Nautiloidea-Oncocerida, 277-319. In MOORE, R.C. (ed.) Treatise on Invertebrate Paleontology, Part K, Mollusca 3, Cephalopoda. Geological Society of America \& The University of Kansas Press, Boulder \& Colorado.

SwEET, W.C. \& LeUTZE, W.P. 1956. A restudy of the Silurian nautiloid genus Pristeroceras Ruedemann. Journal of Paleontology 30(5), 1159-1164.

ŠTORCH, P. 1994. Graptolite biostratigraphy of the Lower Silurian (Llandovery and Wenlock) of Bohemia. Geological Journal 29, 137-165.

S̆TORCH, P. 1995. Upper Silurian (upper Ludlow) graptolites of the $N$. inexpectatus and N. kozlowskii biozones from Kosov Quarry near Beroun (Barrandian area, Bohemia). Věstník Českého geologického ústavu 70, 65-89.

TEICHERT, C. 1964. Morphology of hard parts, 13-53. In MOORE, R.C. (ed.) Treatise on Invertebrate Paleontology, Part K, Mollusca 3. The Geological Society of America, Lawrence.

TEICHERT, C. 1988. Main features of cephalopod evolution, 11-79. In Clarke, M.R. \& TRUEMAN, E.R. (eds) The Mollusca, vol. 12, Paleontology and neontology of cephalopods. Academic Press, San Diego.

TUREK, V. 1992. Ortocerové vápence a hlavonožci hraničních poloh kopaninského a přídolského souvrství v činném lomu na Kosově u Berouna [Orthoceras Limestones and cephalopds of the Kopanina/Př́idolí boundary beds (Silurian) in active part of the Kosov quarry near Beroun]. Časopis Národního muzea, Řada př́rodovědná 158 (1-4), 108.

TUREK, V. 1974. Poznámky k sedimentaci „ortocerových vápencü" Barrandienu (Remarks on sedimentation of "orthoceratid limestones" in the Barrandian). Časopis pro mineralogii a geologii 19(2), 165-169.

TUREK, V. 1990. Color patterns on Silurian and Devonian cephalopods of Central Bohemia, 81. In Abstracts $3^{\text {rd }}$ Symposium of $\mathrm{Ce}$ phalopods: Present and Past. Université Claude Bernard, Lyon.

TUREK, V. 2004. Some special cases of preservation of colour markings in Lower Palaeozoic nautiloids, 103. 5. paleontologická konferencia. Zborník abstraktov. Štátny geologický ústav Dionýza Štúra, Bratislava.

TUREK, V. 2008. Boionautilus gen. nov. from the Silurian of Europe and North Africa (Nautiloidea, Tarphycerida. Bulletin of Geosciences 83(2), 141-152.

DOI 10.3140/bull.geosci.2008.02.141

TUREK, V. 2009. Colour patterns in Early Devonian cephalopods from the Barrandian Area: Taphonomy and taxonomy. Acta Palaeontologica Polonica 54(3), 491-502.

TUREK, V. \& MAREK, J. 1986. Notes on the phylogeny of the Nautiloidea. Paläontologische Zeitschrift 60 (3/4), 245-253.

VOKÁČ, V. 1999. Trilobitová společenstva hraničního intervalu Ludlow-př́idolí (silur) v novém profilu v lomu Kosov u Berouna (pražská pánev, Čechy). Palaeontologia Bohemiae 5(9), 70-74.

WESTERMANN, G.E.G. 1998. Life habits of nautiloids, 263-298. In SAVAZZI, E. (ed.) Functional morphology of the invertebrate skeleton. John Wiley, London.

ZHURAVLEVA, F.A. 1972a. Devonskie nautiloidei Otrjad Discosorida. Trudy Paleontologicheskogo Instituta Akademii Nauk SSSR 134, 1-320.

ZHURAVLEVA, F.A. 1972b. Otpechatky muskulov-retraktorov u devonskich ptenoceratid. Paleontologicheskii Zhurnal 1972(1), 134-137. 